\title{
Ethnic variation in respiratory morbidity and lung function in childhood
}

\author{
I D A JOHNSTON, J M BLAND, H R ANDERSON
}

From the Department of Clinical Epidemiology and Social Medicine, St George's Hospital Medical School, London, and University Hospital, Nottingham

ABSTRACT In a population of 5689 primary schoolchildren there were few important differences: between children of European $(n=5287)$, African $(n=198)$, and Indian origin $(n=204)$ in the prevalence of a history of past respiratory illnesses or current respiratory symptoms. The reported $\mathrm{N}$ 12 month period prevalence of the symptom "ever wheezy" was $15 \%, 18 \%$, and $17 \%$ respectively음 in the three ethnic groups (differences not significant). In a subsample of 973 European, 47 African,and 40 Indian children forced expiratory volume in one second $\left(F E V_{1}\right)$ and forced vital capacity (FVC) were significantly lower by $12 \%$ and $13 \%$ in Africans and by $8 \%$ and $9 \%$ in Indians than in Europeans after adjustment to the group mean height of $128 \mathrm{~cm}$. No significant ethnic variation was $\vec{\omega}_{\infty}$ found for forced mid expiratory flow, $\mathrm{FEV}_{1} / \mathrm{FVC}$, or mean transit time. Since the lung function ${ }^{v}$ studies were performed on a sample from a large population with little variation in respiratoryo mobidity, the differences are likely to reflect human biological differences. Separate prediction $\leqslant$ equations need to be developed for the different ethnic groups in childhood.

\section{Introduction}

Although it has been known for many years that there are ethnic differences in lung function, ${ }^{1}$ most comparisons between ethnic groups in childhood have been made between children of European and African origins in the United States ${ }^{2-8}$ or Jamaica. ${ }^{9}$ Despite the substantial size of the non-European ethnic groups in Britain there has been very little study of ethnic variation in lung function in this country ${ }^{10} 32$ and only one published statistical analysis comparing the lung function in European, African, and Indian children in the same population either in Britain or elsewhere.

Even less is known about the comparative respiratory morbidity in European, African, and Indian children. Such information would throw light on the relative roles of constitutional and environmental factors in the aetiology of respiratory disease in children. The few data that are available suggest that wheezing illness may be more common in African children born in Britain than in Europeans. ${ }^{1112}$ Adults of African origin have been shown to have a lower prevalence of

\footnotetext{
Address for correspondence: Dr I D A Johnston, D Floor, South Block, University Hospital, Nottingham NG7 2UH. (Reprints will not be available.)
}

Accepted 9 December 1986 chronic bronchitis than Europeans (in the United $\vec{\circ}$ States) ${ }^{13}$ and Indians (in Guyana). ${ }^{14}$

We report the prevalence of respiratory symptoms? and lung function findings in a large ethnically mixed? population of South London primary school children.

\section{Methods}

The data were obtained during a study designed pri-ôำ marily to investigate the effects of whooping cough on subsequent respiratory morbidity and lung function? in primary schoolchildren. ${ }^{15}$ In this study we sent a respiratory questionnaire to the parents of all chil-o dren in the same school class as those children we hadr previously identified as having had whooping cough: Replies were received from $80 \%$ of 7337 parents. Theo questionnaire obtained data about previous respiratory illnesses and current (last 12 months) respiratorye symptoms and about hospital admissions, breasto feeding history, family size, parental occupation, par ental smoking, and family history of wheezing illness? All children whose parents had been sent the respiratory questionnaire were classified by appearance into those of "European," "African," and "Indian" descent and "others" (including those of mixed race). Ir $\mathbb{B}$ our study area, $70 \%$ of children of "African" descent were from families who had emigrated from the 
Caribbean and $84 \%$ of children of "Indian" descent were from the Indian subcontinent. The ethnic group of children absent from school was determined by inquiry from both the class teacher and the school nurse. The three main ethnic groups, European, African, and Indian, were compared with respect to the data obtained from the respiratory questionnaire.

Subsequently a sample of 1071 children was selected for lung function testing at school. The methods of selection have been described in detail elsewhere. ${ }^{15}$ In brief, 360 children with a history of whooping cough were selected. For each of these, two school class controls with no previous whooping cough, matched for sex but not ethnicity, were randomly selected from parental responses to the respiratory questionnaire (total 711 , only one control being available for nine of the cases). The lung function sample was compared with the remainder of the population from which it was drawn with respect to the respiratory questionnaire data to assess representativeness.

Physical examination and lung function testing was performed by a single observer (IDAJ). No child was excluded (for example, because of respiratory infection) provided that he or she was attending school on the study day. Weight was measured to $0 \cdot 1 \mathrm{~kg}$ with portable field survey scales (CMS Weighing Equipment Ltd) and height to $0.001 \mathrm{~m}$ with a portable stadiometer (Holtain Ltd). Skinfold thicknesses at four sites (biceps, triceps, subscapular, and anterior superior iliac spine) were measured on the left side to $0.1 \mathrm{~mm}$ (Harpenden Skinfold Calipers), together with arm circumference to $1 \mathrm{~mm}$. The chest was examined and the presence of upper respiratory tract infection noted.

Lung function testing was performed with an Smodel spirometer (Vitalograph Ltd), in the standing position for younger children and the sitting position for older children. Noseclips were not routinely worn. After at least two practice attempts, three satisfactory blows were recorded. Provided that the lung function record met standard criteria for acceptance, ${ }^{16}$ the highest values for the forced expiratory volume in 0.75 second $\left(\mathrm{FEV}_{0.75}\right)$ and 1 second $\left(\mathrm{FEV}_{1}\right)$ and forced vital capacity (FVC) were selected for analysis. The forced expiratory ratio $\mathrm{FEV}_{1} / \mathrm{FVC} \times 100$ (FEV\%) was determined, and the forced expiratory flow between $25 \%$ and $75 \%$ of the FVC (FEF) was estimated from the curve with the largest $\mathrm{FEV}_{1}$ and FVC by means of plastic overlay. A microprocessor (Function Analyser, Vitalograph Ltd) provided a printout of mean transit time (MTT). All volumes were converted to body temperature and pressure. ${ }^{1}$

Skinfold thicknesses were transformed to a logarithmic scale by means of an equation: skinfold transform $(\mathrm{ST})=100 \times \log _{10}$ (reading in $\left.0.1 \mathrm{~mm}-18\right) .{ }^{17}$ Fat free mass (FFM) was derived from the skinfold measurements on the basis of published equations. ${ }^{18}$ Stepwise regression of the lung function indices on age and all anthropometric variables showed that by far the most important independent variable for $\mathrm{FEV}_{0.75}, \mathrm{FEV}_{1}, \mathrm{FVC}$, and FEF was height, which was then used alone in subsequent analysis. A linear model was chosen since it accounted for a higher proportion of the variance of $\mathrm{FEV}_{0.75}, \mathrm{FEV}_{1}, \mathrm{FVC}$, and FEF than various logarithmic models. Analysis of covariance was then performed to determine the effects of ethnicity. $\chi^{2}$ tests were used for comparisons of categorical variables and $t$ tests were used for continuous variables.

All relevant ethical committees approved the study and all parents gave signed consent to the examination of their child.

\section{Results}

Replies to the respiratory questionnaire were received from the parents of 5287 European, 198 African, and 204 Indian children, response rates of $80 \%, 60 \%$, and $63 \%$ respectively. One hundred and seventeen replies

Table 1 Background data (\%n) on the children in the samples

\begin{tabular}{|c|c|c|c|c|c|c|}
\hline & \multicolumn{3}{|c|}{ Whole sample } & \multicolumn{3}{|c|}{ Lung function sample } \\
\hline & $\begin{array}{l}\text { European } \\
(n=5287)\end{array}$ & $\begin{array}{l}\text { African } \\
(n=198)\end{array}$ & $\begin{array}{l}\text { Indian } \\
(n=204)\end{array}$ & $\begin{array}{l}\text { European } \\
(n=973)\end{array}$ & $\begin{array}{l}\text { African } \\
(n=47)\end{array}$ & $\begin{array}{l}\text { Indian } \\
(n=40)\end{array}$ \\
\hline $\begin{array}{l}\text { †Manual social class*** } \\
\text { Parental smoking*** } \\
\text { Breast fed*** } \\
\text { Siblings aged }<5 y \\
\text { Hospital admission ever } \\
\text { Family history of asthma } \\
\text { Family history of wheeze }\end{array}$ & $\begin{array}{l}50 \\
59 \\
41 \\
31 \\
68 \\
39 \\
14 \\
19\end{array}$ & $\begin{array}{l}58 \\
44 \\
68 \\
34 \\
64 \\
35 \\
11 \\
15\end{array}$ & $\begin{array}{r}29 \\
39 \\
56 \\
29 \\
65 \\
33 \\
9 \\
12\end{array}$ & $\begin{array}{l}53 \\
63 \\
38 \\
30 \\
69 \\
43 \\
16 \\
21\end{array}$ & $\begin{array}{r}44 \\
47 \\
68 \\
47 \\
64 \\
28 \\
2 \\
2\end{array}$ & $\begin{array}{r}41 \\
40 \\
65 \\
30 \\
68 \\
38 \\
13 \\
3\end{array}$ \\
\hline
\end{tabular}

†Percentages of those for whom data were recorded.

${ }^{*} p<0.05 ;{ }^{* * *} p<0.001$ (significant differences between ethnic groups found only within whole sample). 
Table 2 History of past chest illnesses ( $\% n$ )

\begin{tabular}{|c|c|c|c|c|c|c|}
\hline & \multicolumn{3}{|l|}{ Whole sample } & \multicolumn{3}{|c|}{ Lung function sample } \\
\hline & $\begin{array}{l}\text { European } \\
(n=5287)\end{array}$ & $\begin{array}{l}\text { African } \\
(n=198)\end{array}$ & $\begin{array}{l}\text { Indian } \\
(n=204)\end{array}$ & $\begin{array}{l}\text { European } \\
(n=973)\end{array}$ & $\begin{array}{l}\text { African } \\
(n=47)\end{array}$ & $\begin{array}{l}\text { Indian } \\
(n=40)\end{array}$ \\
\hline $\begin{array}{l}\text { Croup*** } \\
\text { Pneumonia } \\
\text { Whooping cough*** } \\
\text { Bronchitis* } \\
\text { Wheezy bronchitis } \\
\text { Wheeze } \\
\text { Asthma } \\
\text { Wheezy bronchitis or wheeze or asthma }\end{array}$ & $\begin{array}{r}12 \\
3 \\
19 \\
9 \\
9 \\
11 \\
5 \\
17\end{array}$ & $\begin{array}{r}3 \\
3 \\
12 \\
6 \\
7 \\
73 \\
13 \\
7 \\
20\end{array}$ & $\begin{array}{r}2 \\
1 \\
9 \\
4 \\
6 \\
9 \\
3 \\
13\end{array}$ & $\begin{array}{r}12 \\
5 \\
35 \\
11 \\
11 \\
11 \\
5 \\
18\end{array}$ & $\begin{array}{r}6 \\
6 \\
32 \\
9 \\
4 \\
15 \\
9 \\
21\end{array}$ & $\begin{array}{r}3 \\
0 \\
10 \\
10 \\
8 \\
15 \\
3 \\
18\end{array}$ \\
\hline
\end{tabular}

${ }^{*} \mathrm{p}<0.05 ;{ }^{* * *} \mathrm{p}<0.001$ (significant differences between ethnic groups only found within whole sample).

Table 3 Respiratory symptoms in the previous 12 months ( $\% n$ )

\begin{tabular}{|c|c|c|c|c|c|c|}
\hline & \multicolumn{3}{|c|}{ Whole sample } & \multicolumn{3}{|c|}{ Lung function sample } \\
\hline & $\begin{array}{l}\text { European } \\
(n=5287)\end{array}$ & $\begin{array}{l}\text { African } \\
(n=198)\end{array}$ & $\begin{array}{l}\text { Indian } \\
(n=204)\end{array}$ & $\begin{array}{l}\text { European } \\
(n=973)\end{array}$ & $\begin{array}{l}\text { African } \\
(n=47)\end{array}$ & $\begin{array}{l}\text { Indian } \\
(n=40)\end{array}$ \\
\hline $\begin{array}{l}\text { Morning cough } \\
\text { Day or night cough** } \\
\text { Morning phlegm } \\
\text { Day or night phlegm } \\
\text { Chest ever wheezy } \\
\text { More breathless than others*** } \\
\text { Cough or cold in previous two weeks }\end{array}$ & $\begin{array}{r}8 \\
16 \\
3 \\
4 \\
15 \\
8 \\
33\end{array}$ & $\begin{array}{r}12 \\
25 \\
5 \\
5 \\
18 \\
11 \\
40\end{array}$ & $\begin{array}{r}9 \\
15 \\
4 \\
5 \\
17 \\
13 \\
35\end{array}$ & $\begin{array}{r}9 \\
16 \\
4 \\
6 \\
16 \\
8 \\
35\end{array}$ & $\begin{array}{r}13 \\
32 \\
4 \\
2 \\
21 \\
11 \\
36\end{array}$ & $\begin{array}{r}3 \\
8 \\
3 \\
3 \\
18 \\
13 \\
28\end{array}$ \\
\hline
\end{tabular}

were received from parents of other or mixed ethnic groups and these were not analysed further. Fifty per cent of the children were boys. Twenty nine per cent were aged 5-6 years, 41\% 7-8 years, 21\% 9-10 years, and 9\% 11-13 years. There were no significant differences in the sex or age distribution between the three ethnic groups. There were, however, significant differences in the distribution of social class, parental smoking, history of breast feeding (all $\mathrm{p}<0.001$ ), and a family history of wheezing illness $(p<0.05)$ (table 1). No differences were found in the proportions of children with siblings aged under five or 5-15 years. Significantly more European children had had croup, whooping cough, and bronchitis but no significant differences were found in the history of $\frac{\bar{a}}{\exists}$ wheezing illness (table 2). The distribution of current respiratory symptoms showed significant differences only for day or night cough and whether the child was more breathless on running than others (table 3). In particular the 12 months period prevalence of wheezed was very similar in the three groups at $15 \%$ for Euro-peans, $18 \%$ for Africans, and $17 \%$ for Indians.

Of the lung function sample, 973 were European, 47 African, and 40 Indian and the proportion of boys was $44 \%, 55 \%$, and $55 \%$. Twenty six per cent of theo sample were aged $5-6$ years $(26 \%, 32 \%$ and $23 \%$ for European, African, and Indian children); 47\% 7-80 years $(48 \%, 45 \%, 40 \%) ; 18 \% 9-10$ years $(18 \%, 13 \%$,

Table 4 Mean age and anthropometric data adjusted for sex (lung function sample)

\begin{tabular}{|c|c|c|c|c|}
\hline & European $(n=973)$ & African $(n=47)$ & Indian $(n=40)$ & $p^{*}$ \\
\hline $\begin{array}{l}\text { Age (y) } \\
\text { Height (cm) } \\
\text { Weight (kg) } \\
\text { Biceps ST } \\
\text { Triceps ST } \\
\text { Subscapular ST } \\
\text { Asis ST } \\
\text { Arm circumference (cm) } \\
\text { Fat free mass (kg) }\end{array}$ & $\begin{array}{r}7 \cdot 8 \\
128 \cdot 1 \\
26 \cdot 8 \\
163 \cdot 4 \\
194 \cdot 3 \\
161 \cdot 2 \\
169 \cdot 1 \\
19 \cdot 4 \\
21 \cdot 3\end{array}$ & $\begin{array}{r}7 \cdot 5 \\
128 \cdot 6 \\
26 \cdot 9 \\
151 \cdot 4 \\
185 \cdot 1 \\
158 \cdot 2 \\
158 \cdot 9 \\
19 \cdot 4 \\
21 \cdot 8\end{array}$ & $\begin{array}{r}8 \cdot 1 \\
128 \cdot 7 \\
27 \cdot 3 \\
166 \cdot 5 \\
197 \cdot 7 \\
171 \cdot 7 \\
182 \cdot 7 \\
19 \cdot 3 \\
21 \cdot 1\end{array}$ & $\begin{array}{l}0.2 \\
0.9 \\
0.9 \\
0.001 \\
<0.001 \\
0.003 \\
<0.001 \\
0.9 \\
0.8\end{array}$ \\
\hline \multicolumn{5}{|c|}{$\begin{array}{l}\text { *Analysis of variance. } \\
\text { ST-skinfold transform; Asis-anterior superior iliac spine. }\end{array}$} \\
\hline
\end{tabular}


Ethnic variation in respiratory morbidity and lung function in childhood

Table 5 Mean lung function adjusted to height $128 \mathrm{~cm}$ and $95 \%$ confidence intervals of differences between ethnic groups

\begin{tabular}{|c|c|c|c|c|c|c|c|}
\hline & European (n) & African $(n)$ & Indian (n) & $S D$ & European-African & European-Indian & Indian-African \\
\hline $\begin{array}{l}\mathrm{EV}_{\mathbf{0 . 7 5}} \\
\mathrm{M}^{\mathrm{F}} \\
\mathrm{F} \\
\text { All }\end{array}$ & $\begin{array}{l}1.61(423) \\
1.55(544) \\
1.58(967)\end{array}$ & $\begin{array}{l}1.41(25) \\
1.38(20) \\
1.40(45)\end{array}$ & $\begin{array}{l}1.48(22) \\
1.47(18) \\
1.48(40)\end{array}$ & $\begin{array}{l}0 \cdot 19 \\
0 \cdot 16 \\
0 \cdot 18\end{array}$ & $\begin{array}{l}0.20^{*}(0.06 \text { to } 0.34) \\
0.17^{*}(0.04 \text { to } 0.30) \\
0.18^{*}(0.08 \text { to } 0.27)\end{array}$ & $\begin{array}{l}0.13^{*}(0.04 \text { to } 0.21) \\
0.08^{*}(0.01 \text { to } 0.16) \\
0 \cdot 10^{*}(0.04 \text { to } 0.16)\end{array}$ & $\begin{array}{l}0.07(-0.04 \text { to } 0.18) \\
0.09(-0.02 \text { to } 0.19) \\
0.08^{*}(0.01 \text { to } 0.16)\end{array}$ \\
\hline $\begin{array}{l}M^{1} \\
\text { F } \\
\text { All } \\
\text { VCt }\end{array}$ & $\begin{array}{l}1.74(417) \\
1.67(539) \\
1.70(956)\end{array}$ & $\begin{array}{l}1.51(25) \\
1.47(19) \\
1.49(44)\end{array}$ & $\begin{array}{l}1 \cdot 57(21) \\
1 \cdot 56(18) \\
1 \cdot 56(39)\end{array}$ & $\begin{array}{l}0.21 \\
0 \cdot 17 \\
0 \cdot 18\end{array}$ & $\begin{array}{l}0.23^{*}(0.09 \text { to } 0.38) \\
0.20^{*}(0.06 \text { to } 0.34) \\
0.21^{*}(0.11 \text { to } 0.31)\end{array}$ & $\begin{array}{l}0 \cdot 17^{*}(0.08 \text { to } 0.26) \\
0 \cdot 11^{*}(0.03 \text { to } 0 \cdot 19) \\
0 \cdot 14^{*}(0.08 \text { to } 0.20)\end{array}$ & $\begin{array}{l}0.06(-0.06 \text { to } 0.18) \\
0.09(-0.02 \text { to } 0.20) \\
0.07(-0.01 \text { to } 0.15)\end{array}$ \\
\hline $\begin{array}{l}\mathbf{M} \\
\mathbf{F} \\
\text { All } \\
\text { FF. }\end{array}$ & $\begin{array}{l}1.99(401) \\
1.86(509) \\
1.92(910)\end{array}$ & $\begin{array}{l}1 \cdot 70(24) \\
1.62(19) \\
1.67(43)\end{array}$ & $\begin{array}{l}1 \cdot 77(21) \\
1 \cdot 71(18) \\
1 \cdot 74(39)\end{array}$ & $\begin{array}{l}0.21 \\
0 \cdot 18 \\
0 \cdot 21\end{array}$ & $\begin{array}{l}0.28^{*}(0.13 \text { to } 0.44) \\
0.23^{*}(0.08 \text { to } 0.38) \\
0.25^{*}(0.13 \text { to } 0.36)\end{array}$ & $\begin{array}{l}0.22^{*}(0.13 \text { to } 0.31) \\
0.15^{*}(0.06 \text { to } 0.24) \\
0.18^{*}(0.11 \text { to } 0.25)\end{array}$ & $\begin{array}{l}0.06(-0.06 \text { to } 0.19) \\
0.08(-0.04 \text { to } 0.20) \\
0.07(-0.02 \text { to } 0.16)\end{array}$ \\
\hline $\begin{array}{l}\text { EF: } \\
\text { M } \\
\text { F } \\
\text { All }\end{array}$ & $\begin{array}{l}2 \cdot 09(401) \\
2 \cdot 17(507) \\
2 \cdot 13(908)\end{array}$ & $\begin{array}{l}1.96(24) \\
1.99(19) \\
1.98(43)\end{array}$ & $\begin{array}{l}2 \cdot 14(19) \\
2 \cdot 21(18) \\
2 \cdot 17(37)\end{array}$ & $\begin{array}{l}0.52 \\
0.47 \\
0.49\end{array}$ & $\begin{array}{l}0.13(-0.26 \text { to } 0.52) \\
0.18(-0.20 \text { to } 0.55) \\
0.15(-0.12 \text { to } 0.42)\end{array}$ & $\begin{array}{l}-0.06(-0.30 \text { to } 0.18) \\
-0.04(-0.26 \text { to } 0.18) \\
-0.05(-0.21 \text { to } 0.11)\end{array}$ & $\begin{array}{l}0.18(-0.13 \text { to } 0.50) \\
0.22(-0.08 \text { to } 0.52) \\
0.20(-0.02 \text { to } 0.41)\end{array}$ \\
\hline
\end{tabular}

Interaction between ethnicity and height; differences and confidence intervals relevant for height of $128 \mathrm{~cm}$ only. $\mathrm{p}<0.05$ (analysis of covariance).

$20 \%)$; and $9 \% 11-13$ years $(9 \%, 11 \%, 17 \%)$. The ethnic differences in age distribution were not significant. The pattern of respiratory symptoms and illnesses among the lung function sample closely resembled that of the remainder of the population from which it was drawn. In the lung function group the proportion of European and African children (though not Indian) who had had whooping cough was higher, as would be expected from the selection procedure, and the proportion of African and Indian children with a family history of wheezing illness was significantly lower. Within the lung function sample a history of either wheezy bronchitis, wheeze, or asthma at some time was reported in very similar proportions of the ethnic groups (table 2).

The mean age, height, weight, arm circumference, and FFM (table 4) did not differ significantly between ethnic groups, but the effect of ethnicity was significant for all skinfold transforms (Indian children $>$ European $>$ African). On auscultation wheeze was found in $7 \%$ of European, $9 \%$ of African, and $10 \%$ of Indian children. The mean values of the height dependent variables $\mathrm{FEV}_{0.75}, \mathrm{FEV}_{1}, \mathrm{FVC}$, and FEF for each ethnic group were adjusted to the overall mean height of the subjects, $128 \mathrm{~cm}$. At this height, $\mathrm{FEV}_{\mathbf{0 . 7 5}}, \mathrm{FEV}_{1}$, and FVC were significantly lower in African children (by $11 \%, 12 \%$, and $13 \%$ ) and in Indian children (by $6 \%, 8 \%$, and $9 \%$ ) than in European children (table 5). These differences were similar and still significant for boys and girls separately, with consistently slightly larger differences found for boys. For FVC there was a significant interaction of ethnic group with height in that the regression lines for European and Indian children diverged significantly with increasing height, but in view of the relatively small numbers in the nonEuropean groups we have for simplicity presented the data as though there were no interaction. African children had lower $\mathrm{FEV}_{0.75}, \mathrm{FEV}_{1}$, and FVC than Indian children, by $5 \%, 4 \%$, and $4 \%$; but these differences were not significant except for $\mathrm{FEV}_{0.75}$ No significant differences were found in FEF between ethnic groups, though Indians, both boys and girls, had higher mean values than Europeans and Africans had the lowest values. The regression lines from anal-

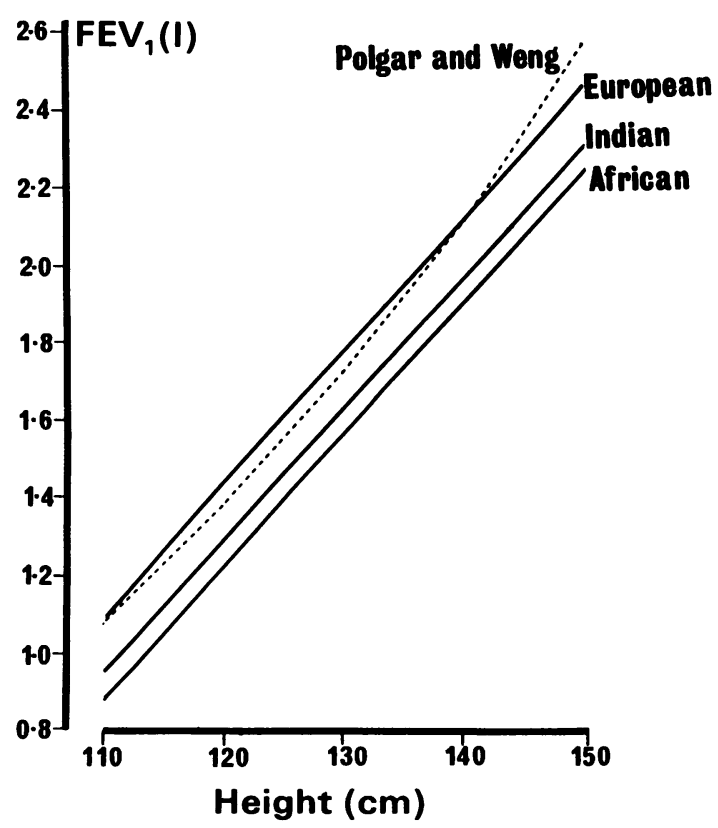

$F E V_{1}$ in the three ethnic groups (regression lines derived from analysis of covariance) with summary curve of Polgar and Weng $^{18}$ for comparison. 
Table 6 Mean (SD) forced expiratory ratios (FEV\%) and mean transit times (MTT)

\begin{tabular}{|c|c|c|c|c|c|c|c|c|c|}
\hline & \multicolumn{3}{|c|}{ European } & \multicolumn{3}{|c|}{ African } & \multicolumn{3}{|l|}{ Indian } \\
\hline & Mean & (n) & $S D$ & Mean & $(n)$ & $S D$ & Mean & $(n)$ & $S D$ \\
\hline \multicolumn{10}{|l|}{ FEV (\%) } \\
\hline M & $87 \cdot 7$ & $(401)$ & $5 \cdot 3$ & $89 \cdot 4$ & (24) & $3 \cdot 7$ & $89 \cdot 2$ & (21) & $5 \cdot 8$ \\
\hline $\mathbf{F}$ & $90 \cdot 1$ & (509) & $4 \cdot 8$ & $90 \cdot 6$ & (19) & $4 \cdot 1$ & $91 \cdot 3$ & (18) & 3.0 \\
\hline All & $89 \cdot 0$ & (910) & $5 \cdot 1$ & 89.9 & (43) & 3.9 & $90 \cdot 3$ & (39) & $4 \cdot 8$ \\
\hline \multicolumn{10}{|l|}{ MTT (s) } \\
\hline M & 0.49 & $(290)$ & $0 \cdot 11$ & 0.46 & (12) & 0.09 & 0.49 & (13) & 0.13 \\
\hline $\mathbf{F}$ & 0.45 & (327) & $0 \cdot 10$ & 0.45 & (10) & 0.08 & 0.41 & (11) & 0.08 \\
\hline All & 0.47 & (617) & $0 \cdot 11$ & 0.45 & (22) & 0.08 & 0.46 & (24) & 0.12 \\
\hline
\end{tabular}

No differences significant.

ysis of covariance for $\mathrm{FEV}_{1}$ for each group over the range $110-150 \mathrm{~cm}$, which included $95 \%$ of the subjects, are shown graphically (figure), with the summary curve from Polgar and Weng. ${ }^{19}$ Both African and Indian children had a slightly higher mean FEV\% and lower MTT than European children, but the differences were not significant (table 6).

Analysis of the effect of respiratory illnesses and symptoms on lung function in the group as a whole showed that a past history of pneumonia or wheezing illness and a current history of wheeze or breathlessness were highly significantly associated with FEV $_{1}$ and FEF. A past history of wheezing illness was, however, associated with an increase in FVC. We have previously shown that a history of whooping cough has no effect on lung function in children in general $^{15}$; further analyses for the purposes of the present study showed no significant effect of whooping cough on any index of lung function in any ethnic group.

\section{Discussion}

The question of whether there is ethnic variation in the experience of respiratory illnesses and symptoms is important both clinically, since children of nonEuropean origin comprised over $11 \%$ of our population, and epidemiologically, since the relative contributions of constitutional and environmental factors to respiratory disease are not clearly established. Neither is it known whether differing respiratory morbidity is reflected in differing lung function or vice versa. We therefore took the opportunity to study both respiratory morbidity and lung function in different ethnic groups within the same population.

In this study current respiratory symptoms were least common in European children, though significant differences were found only for cough during the day or night and breathlessness, which were commonest in African and Indian children respectively. Past croup, whooping cough, and bronchitis were reported more commonly in European children. All respiratory symptoms and past illnesses (with the exception of current breathlessness) were consistently reported as commonly or more com- monly in Africans than in Indians, though most oti these differences were small and non-significant.

In view of our sampling methods the study cannot be considered to be a true prevalence survey. Never theless, our symptom prevalence rates are similar to those found in the few previous studies in which com parable questions have been asked. The $16 \%$ preva lence rate for chronic cough in our study is similar to that in certain earlier studies ${ }^{2021}$ and, while the 180 month prevalence of wheeze $(15 \%)$ is somewhat higher than the $11 \%$ recorded over one to two yeare by others, ${ }^{22}{ }^{23}$ these latter studies inquired about eps sodes or attacks of wheeze rather than whether the chest was ever wheezy. Our lifetime prevalence o\% wheezing illness $(17 \%)$ compares with that of $18 \%$ from the study of McNicol and Williams. ${ }^{24}$

Despite the possibility that sampling methods make interpretation of the absolute prevalence rates more difficult, internal comparisons within the population-namely, between ethnic groups-ares valid. Several other factors, however, may have influenced such comparisons. Firstly, the responsê rate was slightly lower in both the non-Europeagroups and, because we were unable to evaluate now. responders, this might have introduced bias. See ondly, whooping cough was more common in Europeans and we have previously reported this dif ease to be associated with increased respiratory mor bidity. ${ }^{15}$ The excess of whooping cough is no? however, large enough to have had a material effeat on the comparison of symptom prevalence in the present study. Thirdly, we do not know how culturat factors influence the understanding of and respons to the respiratory questionnaire. Fourthly, there were significant differences between ethnic groups in socid class, parental smoking, and family history of wheee ing illnesses, all factors known to influence respira? tory morbidity, 202125 and in breast feeding, foo which the evidence is conflicting. ${ }^{26}$ With the excep tion of the lower social class of the African childrew however, all these factors would be expected to have reduced respiratory morbidity in the non-European groups. Finally, country of birth is an important pos sible confounding factor. A lower prevalence of asthma and wheeze has been found in non-Europea 
children born abroad ${ }^{11}$ and childhood asthma is uncommon in rural areas of Nigeria and Gambia ${ }^{2728}$ and India, ${ }^{29}$ though more recently an $8 \%$ prevalence of asthma has been found in children in rural Tanzania. ${ }^{30}$ We do not know the country of birth of our children but, at the time of the study, only $3 \%$ of all children aged 5-15 years in our study area with parents of West Indian origin and $32 \%$ of those with parents of Indian origin had been born abroad. ${ }^{31}$ Since the figures are even smaller for younger children and $90 \%$ of our sample were aged 10 years or younger, the great majority of our sample is likely to have been born in Britain. We conclude, then, that in this population of nearly 5700 London primary schoolchildren there was little variation in respiratory morbidity between ethnic groups.

Ventilatory capacity was significantly lower in African and Indian children than in Europeans. African children had lower values than Indian children but the differences were significant only for $\mathrm{FEV}_{\mathbf{0 . 7 5}}$. Similar differences were found for boys and girls separately. No significant ethnic differences were found in the derived indices FEF, FEV\%, or MTT. Although the methods of selection had the result that one third of the lung function subjects had had whooping cough, we have previously shown that this disease has no effect on subsequent lung function, ${ }^{15}$ and the present study confirms this for the different ethnic groups separately. We have not derived prediction equations in view of the methods of selection and the small numbers of non-Europeans; but comparisons between ethnic groups are valid and unlikely to be affected by selection bias or technical factors, since all measurements were made by a single observer and coefficients of variation of the spirometric indices compare well with the results of previous studies of childhood lung function. ${ }^{119}$ Furthermore, the regression lines for Europeans for the height dependent variables are close to the summary lines of Polgar and Weng. ${ }^{19}$ The data on mean transit time, should, however, be interpreted cautiously, as the measurement of MTT with the function analyser has not been formally validated.

In two previous studies comparing the three ethnic groups ventilatory capacity in childhood was also considerably lower in Indian and African children, ${ }^{1032}$ but only one of these studies ${ }^{32}$ presented any statistical comparison and neither reported comparisons of respiratory morbidity. Comparisons of African and European children alone have revealed differences in forced expiratory volumes of a similar magnitude to those in our own data, ${ }^{2-9}$ with a trend to lower flow rates in Africans ${ }^{689}$ and little difference in FEV \%, ${ }^{7}$ though few studies provide statistical comparisons. ${ }^{8}$ European and Indian children have not previously been compared, but Indian children in India have a VC about $15 \%$ lower than that predicted for Europeans. ${ }^{33}$ In adults differences between Europeans and Africans in forced expiratory volumes sim- ilar to those in children have been documented, ${ }^{34-36}$ Indians having lower values than Africans. ${ }^{3738} \mathrm{Com}$ parisons of Indian and European adults in different populations have shown lower forced volumes but similar or higher FEV\% in Indians, ${ }^{39-42}$ though the differences are highly dependent on geographical area and altitude. ${ }^{42}$

Since the lung function group was sampled from a larger population with little variation in respiratory morbidity, the observed differences are unlikely to be explained by differences in respiratory morbidity. Furthermore, our lung function data for Africans and Europeans are in broad agreement with those from studies performed on subjects with no evidence of past or present respiratory disease. ${ }^{468}$ The differences found are thus likely to be biological in origin. It has been suggested that the fact that Africans have smaller lung volumes than Europeans at the same standing height is due to the smaller ratio of sitting height to standing height in Africans. If this is so, the use of sitting height might allow single prediction equations to be developed that apply to all three ethnic groups. ${ }^{43}$ This is unlikely, however, since others have found that substantial African-European differences in ventilatory capacity remain even when sitting height is used ${ }^{29}$ and that sitting height is no better a predictor of FVC than standing height. ${ }^{44}$ Furthermore, the ratio of sitting height to standing height is similar for Indians and Europeans (JE Cotes, personal communication). Finally, though it may be appropriate in adults to obtain prediction values for other ethnic groups by applying a constant scaling factor to European values, ${ }^{36}$ our findings confirm that this practice may not be valid in childhood. ${ }^{4543}$ We suggest that further study is required to develop separate prediction equations for the different ethnic groups in childhood.

We thank the Department of Health and Social Security for funding the study, and $\mathrm{Mr}$ A Tickle for statistical assistance and Drs JE Cotes and JM Patrick for helpful comments. A copy of the questionnaire used in this study has been lodged with the editor and additional copies may be obtained from the authors on request.

\section{References}

1 Cotes JE. Lung function: assessment and application in medicine. 4th ed. Oxford: Blackwell Scientific Publications, 1979.

2 Smillie WG, Augustine DL. Vital capacity of Negro race. JAMA 1926;87:2055-8.

3 Chehreh MN, Young RC, Viaene H, Ross CW, Scott RB. Spirometric standards for healthy inner-city black children. Am J Dis Child 1973;126:159-63.

4 Binder RE, Mitchell CA, Schoenberg JB, Bouhuys A. Lung function among black and white children. Am Rev Respir Dis 1976;114:955-9. 
5 Schoenberg JB, Beck GJ, Bouhuys A. Growth and decay of pulmonary function in healthy blacks and whites. Respir Physiol 1978;33:367-93.

6 Hsu KHK, Jenkins DE, Hsi BP, Bourhofer E, Thompson V, Tanakawa $\mathbf{N}$, Hsieh GSJ. Ventilatory functions of normal children and young adults: MexicanAmerican, white and black. I. Spirometry. J Pediatr 1979;95:14-23.

7 Dockery DW, Berkey CS, Ware JH, Speizer FE, Ferris BG. Distribution of forced vital capacity and forced expiratory volume in one second in children six to 11 years of age. Am Rev Respir Dis 1983;128:405-12.

8 Strope GL, Helms RW. A longitudinal study of spirometry in young black and young white children. $\mathrm{Am}$ Rev Respir Dis 1984;130:1100-7.

9 Miller GJ, Saunders MJ, Gilson RJC, Ashcroft MT. Lung function of healthy boys and girls in Jamaica in relation to ethnic composition, test exercise performance and habitual physical activity. Thorax 1977; 32:486-96.

10 Yarnell JWG, St Leger AS. Respiratory infections and their influence on lung function in children: a multiple regression analysis. Thorax 1981;36:847-51.

11 Morrison Smith J. The prevalence of asthma and wheezing in children. Br J Dis Chest 1976;70:73-7.

12 Spears $\mathrm{J}$. The prevalence of allergic disease in young British-born school children of different ethnic origin. J R Coll Gen Pract 1975;25:282-5.

13 Massaro D, Cusick A, Katz S. Racial differences in incidence of chronic bronchitis. Am Rev Respir Dis 1965; 92:94-101.

14 Miller GJ, Ashcroft MT. A community survey of respiratory disease among East Indian and African adults in Guyana. Thorax 1971;26:331-8.

15 Johnston IDA, Anderson HR, Lambert HP, Patel S. Respiratory morbidity and lung function after whooping cough. Lancet 1983;ii:1104-8.

16 American Thoracic Society. ATS Statement-Snowbird Workshop on standardisation of spirometry. Am Rev Respir Dis 1979;119:831-8.

17 Tanner JM, Whitehouse RH. Revised standards for triceps and subscapular skinfolds in British children. Arch Dis Child 1975;50:142-5.

18 Durnin JVGA, Rahaman MM. The assessment of the amount of fat in the human body from measurements of skinfold thickness. Br J Nutr 1967;21:681-9.

19 Polgar G, Weng TR. The functional development of the respiratory system. Am Rev Respir Dis 1979;120: 625-95.

20 Colley JRT, Reid DD. Urban and social origins of childhood bronchitis in England and Wales. Br Med J 1970;ii:213-7.

21 Colley JRT. Respiratory symptoms in children and parental smoking and phlegm production. $\mathrm{Br}$ Med J 1974;ii:201-4.

22 Anderson HR, Bailey P, Cooper JS, Palmer JC. Influence of morbidity, illness label, and social, family, and health service factors on drug treatment of childhood asthma. Lancet 1981;ii:1030-2.

23 Lee DA, Winslow NR, Speight ANP, Hey AN. Prevalence and spectrum of asthma in childhood. $\mathrm{Br}$ Med J 1983;286:1256-8.

24 McNicol KN, Williams HE. Spectrum of asthma in children-I. Clinical and physiological components. Br Med J 1973;iv:7-11.
25 Schenker MB, Samet JM, Speizer FE. Risk factors fợ childhood respiratory disease. Am Rev Respir Di 1983;128:1038-43.

26 Burr ML. Does infant feeding affect the risk of allergyo Arch Dis Child 1983;58:561-5.

27 Warrell DA, Fawcett IW, Harrison BDW, et al. Bron chial asthma in the Nigerian savanna region. $Q J M e \overrightarrow{\text { Q }}$ $1975 ; 44: 325-47$.

28 Godfrey RC. Asthma and IgE levels in rural and urbam̃ communities of the Gambia. Clin Allergy 1975;5 201-7.

29 Viswanathan R. The problem of asthma. Indian J Chest Dis 1972;14:277-89.

30 Carswell F, Merrett J, Merrett TG, Meakins RH, Har land PSEG. IgE, parasites and asthma in Tanzania children. Clin Allergy 1977;7:445-53.

31 Office of Population Censuses and Surveys. Country of birth 1981 census. London: HMSO, 1983.

32 Patrick JM, Patel A. Ethnic differences in the growth of lung function in children. Ann Hum Bi@ 1986;13:307-15.

33 Bhattacharya AK, Banerjee S. Vital capacity in childre and young adults in India. Indian $J$ Med Res 1966;54k 62-71.

34 Edwards RHT, Miller GJ, Hearn CED, Cotes JE. Pubo monary function and exercise responses in relation to body composition and ethnic origin in Trinidadiag males. Proc $R$ Soc London B 1972;181:407-20.

35 Lapp NL, Amandus HE, Hall R, Morgan WKC. Lun volumes and flow rates in black and white subject: Thorax 1974;29:185-8.

36 Rossiter CE, Weil H. Ethnic differences in lung function evidence for proportional differences. Int J Epidemi $\widehat{A}$ 1974;3:55-61.

37 Hearn CED. Bagassosis: an epidemiological, enviro mental, and clinical survey. $\mathrm{Br} J$ Ind $\mathrm{Med}$ 1968;25. 267-82.

38 Miller GJ, Ashcroft MT, Swan AV, Beadnell HMSĞ Ethnic variation in forced expiratory volume and forced vital capacity of African and Indian adults Guyana. Am Rev Respir Dis 1970;102:979-81.

39 Cotes JE, Malhotra MS. Differences in lung function between Indians and Europeans [Abstract]. J Physig] 1964;177:17P-8P.

40 Kamat SR, Thiruvengadam KV, Rao TL. A study pulmonary function among Indians and assessment of the Wright peak flow meter in relation to spiromets. for clinical use. Am Rev Respir Dis 1967;96:707-16.

41 Malik MA, Moss E, Lee WR. Prediction values for the ventilatory capacity in male West Pakistani workers in the United Kingdom. Thorax 1972;27:611-9.

42 Cotes JE, Dabbs JM, Hall AM, Lakhera SC, Saunderes MJ, Malhotra MS. Lung function of healthy youst men in India: contributory roles of genetic and entronmental factors. Proc $R$ Soc Lond 1975;191:413-2థ.

43 Hsi BP, Hsu KHK, Jenkins DE. Ventilatory functiọn of normal children and young adults: Mexicano American, white, and black. III. Sitting height as $\vec{a}$ predictor. J Pediatr 1983;102:860-5.

44 Hamill PVV. Forced vital capacity of children 6-f years, United States. Vital and health statistics: Seres 11. Data from the National Health Survey, No I Hyattsville: Department of Health, Education, and Welfare, 1978. DHEW publications: No (PHE) 78-1651. 